\title{
Arkansas: More Signs of Momentum for Republicanism in Post-"Big Three" Arkansas
}

Jay Barth

An analysis of the 2001 Southern Grassroots Party Activists survey of Democratic and Republican party activists in Arkansas highlights the continued strengthening of the Arkansas GOP at the local level in the state, another sign of momentum for the traditional minority party in the state. Continuing trends seen in the first wave of the survey in 1991, Arkansas GOP activists are more united and more dedicated to their party than are their Democratic counterparts in their commitment of time, in their loyalty to their party's candidates, and in their ideological cohesion. One potential barrier to continued Republican development in the state, however, is evidence that the extreme conservatism of rank-and-file GOP activists may impede the party's growth in a state whose electorate has shown an unwavering sentiment for ideological moderation in recent decades.

\section{Introduction}

A decade ago, the first Southern Grassroots Party Activists survey gave initial insights into the nature of local party activists - both chairs and members of party county committees - in Arkansas. In her analysis of the data from that survey, Blair (1995a) noted a number of hints of momentum for the Republican party in the state at the grassroots level despite its being the "other party" in a one-party state (below the presidential level). The second wave of the Southern Grassroots Party Activists survey, completed in 2001, presents a valuable opportunity to check in on the comparative strength of the two parties at the local level and the political, social, and behavioral differences in those in positions of formal leadership from the two parties at the beginning of the $21^{\text {st }}$ century. Perhaps even more importantly, it allows a reexamination of the Republican organizational momentum shown a decade ago. Indeed, once again the comparative vibrancy of Arkansas Republicanism is shown in the 2001 data boding well for its eventual achievement of a true two-party Arkansas politics. That said, the GOP's ideological coherence-a source of strength for an organization qua organization-does threaten to push the Arkansas Republican party to the right of the political mainstream in a state where the votes of moderate independents are essential for any candidate's success.

\footnotetext{
JAY BARTH is associate professor and chair in the Department of Politics at Hendrix College. He gratefully acknowledges the contributions of four research assistants-Jed Cain, Banks Miller, Brooke Owen, and Adrian Watson-in assisting in the collection of data for this project and the work of Robin Hartwick in coordinating several elements of the project.
}

The American Review of Politics, Vol. 24, Summer, 2003: 111-126

(C)2003 The American Review of Politics 


\section{Development of Political Parties in Arkansas}

\section{Electoral Patterns in Arkansas Since 1991}

Much has transpired in Arkansas politics since the time of the 1991 survey. ${ }^{1}$ Most historic, of course, was the election of an Arkansan to the Presidency the following year. While the native son campaigns of 1992 and 1996 did return Arkansas to the Democratic fold in presidential elections following GOP victories in 1980, 1984, and 1988, the last decade has marked a series of modern high points for the Arkansas Republican party. Table 1 presents some key historical electoral data as well as that for the state since the time of the first wave of the Southern Grassroots Party Activists survey.

Despite the unprecedented national prominence gained by Democrat Clinton, a good deal of the Republican success during this period is, somewhat ironically, connected to Clinton's election. Clinton's move to Washington removed the best-developed Democratic electoral organization from the state. Moreover, any number of prospective candidates for political office in the state traveled to Washington with him, leaving behind (at least for eight years) their own electoral ambitions in Arkansas. Huckabee, who would become the state's newest political star, used an opening created by Clinton's departure to take a close special election victory for Lieutenant Governor in 1993. Finally, the Whitewater investigation led, in 1996, to the elevation of Huckabee to the governorship after Governor Jim Guy Tucker's conviction by a federal jury. Huckabee took full advantage of this opportunity, ably handling the crisis surrounding Tucker's fickleness about actually departing the office and, in 1998, gaining the most impressive electoral victory by a GOP governor in the modern era. At present, Huckabee moves toward probable reelection in 2002 with the Democratic Party desperately seeking a legitimate standard bearer to challenge the overwhelmingly popular incumbent.

The retirements of two of Arkansas's most consistent vote gettersDemocratic U.S. Senators David Pryor (in 1996) and Dale Bumpers (in 1998) - provided additional chances for Republican success. And, in 1996, the GOP filled the vacuum left by Pryor's departure by gaining its first U.S. Senate seat at the ballot box with the elevation of U.S. House member Tim Hutchinson. The GOP was unable to take advantage of the similar opening created by Bumpers' retirement in 1998 as former U.S. Representative Blanche Lincoln gained the seat. Still, the period between these two surveys marks an era in which all three of the masterful Democratic politicians whom Blair (1995b) termed the "Big Three" of Arkansas politics left Arkansas's political battlefields leaving a vacuum into which the Republican 
Table 1. Republican Strength in Arkansas, 1960-2000

\begin{tabular}{|c|c|c|c|c|c|c|}
\hline Year & $\begin{array}{c}\text { Percent of } \\
\text { Presidential } \\
\text { Vote }\end{array}$ & $\begin{array}{c}\text { Percent of } \\
\text { Gubernatorial } \\
\text { Vote }\end{array}$ & $\begin{array}{c}\text { Percent of } \\
\text { U.S. Senate } \\
\text { Vote }\end{array}$ & $\begin{array}{l}\text { Percent of } \\
\text { U.S. House } \\
\text { Delegation }\end{array}$ & $\begin{array}{l}\text { Percent of } \\
\text { State House } \\
\text { Delegation }\end{array}$ & $\begin{array}{c}\text { Percent of } \\
\text { State Senate } \\
\text { Delegation }\end{array}$ \\
\hline 1960 & 43.1 & 31.8 & $\mathrm{n} / \mathrm{a}$ & 0.0 & 0.0 & 0.0 \\
\hline 1962 & & 26.7 & 31.3 & 0.0 & 1.0 & 0.0 \\
\hline 1964 & 43.4 & 43.0 & & 0.0 & 1.0 & 0.0 \\
\hline 1966 & & 54.4 & $\mathrm{n} / \mathrm{a}$ & 25.0 & 2.0 & 0.0 \\
\hline 1968 & 31.0 & 52.4 & 40.9 & 25.0 & 4.0 & 2.9 \\
\hline 1970 & & 32.4 & & 25.0 & 2.0 & 2.9 \\
\hline 1972 & 68.8 & 24.6 & 39.1 & 25.0 & 1.0 & 2.9 \\
\hline 1974 & & 34.4 & 15.1 & 25.0 & 2.0 & 2.9 \\
\hline 1976 & 34.9 & 16.7 & & 25.0 & 5.0 & 2.9 \\
\hline 1978 & & 36.6 & 16.6 & 50.0 & 6.0 & 0.0 \\
\hline 1980 & 48.2 & 51.9 & 37.5 & 50.0 & 7.0 & 2.9 \\
\hline 1982 & & 45.3 & & 50.0 & 7.0 & 8.6 \\
\hline 1984 & 60.5 & 37.4 & 42.7 & 25.0 & 9.0 & 11.4 \\
\hline 1986 & & 36.1 & 37.7 & 25.0 & 9.0 & 11.4 \\
\hline 1988 & 54.0 & & & $25.0^{*}$ & 11.0 & 11.4 \\
\hline 1990 & & 42.5 & $\mathrm{n} / \mathrm{a}$ & 25.0 & 9.0 & 11.4 \\
\hline 1992 & 35.5 & & 39.8 & 50.0 & 10.0 & 14.3 \\
\hline 1994 & & 40.2 & & 50.0 & 12.0 & 20.0 \\
\hline 1996 & 36.8 & & 52.7 & 50.0 & 14.0 & 20.0 \\
\hline 1998 & & 59.8 & 41.8 & 50.0 & 25.0 & 17.1 \\
\hline 2000 & 51.3 & & & 25.0 & 30.0 & 22.9 \\
\hline
\end{tabular}

party (led by Huckabee) has partially been able to move. Huckabee is a politician who shares much of the ability of the "Big Three" to relate to rankand-file Arkansans, particularly in an era where the mass media is increasingly relevant in the state's politics.

Even after Republicans had broken the Democrats' lock on victories in statewide elections, election cycle after election cycle passed in Arkansas with little change in the partisan composition of the state legislature. A happening somewhat lost in the intensity of the Clinton victory in 1992 was the passage, via an initiated amendment to the state constitution, of term limits for Arkansas's elected officials. This reform-which fully impacted the state House of Representatives for the 1998 election cycle - assisted Arkansas Republicans in finally making clear inroads into the state House and Senate. As shown in Table 1, three times as many Republicans now hold state House seats than a decade ago. The expansion of term limits to the state Senate will likely have similar ramifications over the next four years particularly in 
those sections of the state-northwest Arkansas and the suburbs of Little Rock-which are fast-growing and most open to Republicanism. These demographic patterns (as well as the increasing openness of younger Arkansas voters to Republican candidates) bode well for the future of the party in the state, although the GOP's continued difficulty in recruiting quality candidates at all levels of state politics serves as a barrier that will be debilitating in the near future.

\section{Party Organization in Arkansas}

The long tradition of weak party organizations in Arkansas, exceptional even by the standards of the one-party South, joins the candidate-centered nature of modern American politics in limiting the development of Arkansas's political parties as organizations. All successful candidates in Arkansas in the modern era-Democrat or Republican-have developed ongoing campaign organizations almost totally independent of their state parties. ${ }^{2}$ And, in both parties, because successful candidates' organizations are independent they are occasionally the seeds of dissention within the party even when those candidates are not in direct competition.

Still, at least at the state level, with some assistance from their national party (particularly in the case of the GOP), both state parties have developed over the past generation the basic infrastructure and staffing to legitimize themselves. For a brief period in the late 1960s and early 1970s, Governor Winthrop Rockefeller poured money into the state Republican Party and his moderate "Rockefeller Republican" followers populated its activists. But, Rockefeller's 1973 death and the Democrats' return to dominance (with a more progressive outlook) left the party, according to one informed analysis a few years later, "perhaps the weakest in the South" (Bass and DeVries 1977, 40). After the 1980 election, the moderate wing of the GOP was effectively "purged" from leadership roles in the party and, as the Reagan era continued, the state GOP began to rebuild as an ideologically cohesive (unambiguously conservative) party. ${ }^{3}$ Despite regular financial crises and constant turnover in leadership, the state GOP began to assemble into an organization that could at least be of assistance to the candidates running under the party label. And, of even more importance, the party began playing a hands-on role in recruiting potential candidates in a purposeful manner through using a targeting system that had first shown success in Texas (Appleton and Ward 1994). After Clinton's election to the White House, the national Republican Party began pushing resources into the Arkansas state party for projects that could potentially lead to home state "black eyes" for the president and state party fundraising was facilitated by Clinton's visibility as a national figure. 
The strong personal organizations of Democratic governors throughout the 1970s and 1980s left little independent role for the state Democratic Party, though it too began to develop an infrastructure akin to parties elsewhere in the country. While weak compared to its brethren state parties in most of the nation, the Arkansas Democratic party fought through a devastating debt in the mid-1990s and has-like the state GOP-become an organization that can supplement still-dominant candidate organizations by offering increasingly sophisticated electoral assistance (direct mail, phone banks, donor lists, opponent and issue research) to its nominees particularly through "coordinated campaigns" that employ a significant number of paid employees in election years. It was, however, much slower to engage in candidate recruitment of the sort carried out, with some success, by the state GOP.

More directly relevant to this project, there is considerable inconsistency for both parties in terms of local party organizational presence. Midway through the last decade, the Democratic Speaker of the state House of Representatives said, "You would be surprised how many House members tell me their county committees do nothing" (Blair and Barth 1996, 29). Because of a 1995 federal court ruling deeming the Arkansas primary election system that required the parties to conduct and fund their own primaries unconstitutional, one of the traditional reasons for the local Democratic county committees' activity has disappeared. The state now pays for primary elections and both parties primary ballots are available at all precincts in the state, a shift that does present an opportunity (unfulfilled to this point) to enhance the relevance of the GOP primary in Arkansas. So, while electoral and demographic forces would suggest that the Republican Party has likely continued to mature at the local level in the state in the last decade, other trends in the way that campaigns and elections operate in the state would make it unsurprising if neither parties' local organizations have developed significantly since 1991. This second wave of the Southern Grassroots Party Activists - that, at many points, explicitly replicates the 1991 study - promises some insights into these competing possibilities.

\section{Grassroots Party Activists, 2001 and 1991}

With only minor exceptions, Democratic and Republican party activists look remarkably similar to their 1991 counterparts in terms of the characteristics near the surface. However, in terms of less visible political traits, Arkansas's party activists have changed in marked ways over the last decade. These shifts - particularly among GOP activists - promise to have significant implications for the future of party politics in the state. 


\section{Who Are Arkansas's Party Activists?}

Democratic party activists have become more diverse in terms of race and gender since 1991, while almost no changes are evident in these demographic characteristics for Republicans. In 1991, despite their vital role in a biracial coalition that had protected Arkansas's Democrats from Republican incursions, only 4.6 percent of Democratic Party activists were AfricanAmerican. Now, as 9.5 percent of the Democratic activists are AfricanAmericans, the party's grassroots leadership more closely resembles the demographics of the state as a whole (according to the 2000 Census, African-Americans composed 12.3 percent of the Arkansas population) although blacks remain slightly underrepresented. Almost no change has occurred on the Republican side with 96 percent of Republicans identifying themselves as white. Despite the attention given to the increase in the Hispanic-American population in certain Arkansas communities, essentially no Latino/Latina presence is yet shown in the ranks of either parties' most active members.

In 1991, a larger percentage of Republican than Democratic Party activists were female. Now, the reverse is true. The percentage of Republican Party activists who are male has increased slightly from 57.5 to 58.7 percent. But, the percentage of male Democratic activists has decreased sharply from 65 to 52.5 percent, making that party closely reflective of the general population.

As shown in Table 2, neither party has been particularly successful at bringing younger citizens into their cadre of local leaders as the population of both parties' activists has aged in the past decade. While the aging of its grassroots leadership continues to be a larger problem for the state's Democrats (Democratic activists over 80 years of age now actually outnumber its activists under 40 !), the relatively youthful Republican party of a decade ago is also grayer. A slight majority (51.7 percent) of GOP activists are now over the age of 60 .

While Arkansas's Democratic local leaders have begun to look more like the state in terms of race and gender, they diverge from their fellow Arkansans more than they did a decade ago on two other key characteristics: family income and education. These results are also shown in Table 1. While the latest Census estimates the average household income in the state to be just over $\$ 37,000$, a majority of Arkansas's Democratic activists have family incomes over $\$ 50,000$. Similarly, while 13.3 percent of Arkansas's general population has completed a college education, three times as many Democratic party activists have completed college with nearly a quarter now holding a graduate or professional degree. Thus, by these measures, the "party of the people" does not reflect the people of Arkansas. 
Table 2. Demographic Characteristics of Arkansas Party Activists, 1991 and 2001

\begin{tabular}{|c|c|c|c|c|}
\hline \multirow{2}{*}{$\begin{array}{l}\text { Demographic } \\
\text { Characteristic }\end{array}$} & \multicolumn{2}{|c|}{ Democrats } & \multicolumn{2}{|c|}{ Republicans } \\
\hline & 1991 & 2001 & 1991 & 2001 \\
\hline \multicolumn{5}{|l|}{ Age } \\
\hline Under 40 & 10.5 & 7.1 & 17.8 & 9.5 \\
\hline $40-49$ & 16.4 & 13.1 & 14.5 & 17.7 \\
\hline $50-59$ & 20.1 & 27.3 & 19.1 & 21.1 \\
\hline $60-69$ & 27.4 & 28.1 & 28.9 & 29.9 \\
\hline $70-79$ & 20.9 & 19.7 & 16.2 & 17.0 \\
\hline Over 80 & 4.7 & 7.4 & 3.5 & 4.8 \\
\hline$(\mathrm{N})$ & $(762)$ & $(366)$ & $(456)$ & (147) \\
\hline \multicolumn{5}{|l|}{ Education } \\
\hline High school or less & 43.2 & 26.1 & 19.6 & 10.1 \\
\hline Some college & 28.8 & 31.2 & 32.9 & 22.2 \\
\hline College graduate & 13.6 & 18.3 & 25.9 & 29.5 \\
\hline Graduate degree & 14.4 & 24.5 & 21.6 & 26.2 \\
\hline$(\mathrm{N})$ & $(784)$ & $(372)$ & $(459)$ & (149) \\
\hline \multicolumn{5}{|l|}{ Family Income } \\
\hline$<\$ 25,000$ & & 11.9 & & 4.3 \\
\hline$\$ 25,000-49,999$ & & 31.2 & & 22.2 \\
\hline$\$ 50,000-74,999$ & & 23.7 & & 32.9 \\
\hline$\$ 75,000-99,999$ & & 15.2 & & 20.7 \\
\hline$\$ 100,000-149,999$ & & 8.8 & & 7.9 \\
\hline$>\$ 150,000$ & & 4.4 & & 9.3 \\
\hline$(\mathrm{N})$ & & $(362)$ & & $(140)$ \\
\hline \multicolumn{5}{|l|}{ Religion } \\
\hline Mainstream Protestant & & 36.1 & & 41.4 \\
\hline Evangelical Protestant & & 44.9 & & 50.3 \\
\hline Black Protestant & & 9.6 & & - \\
\hline Roman Catholic & & 6.4 & & 5.5 \\
\hline Other & & 2.9 & & 2.8 \\
\hline$(\mathrm{N})$ & & $(374)$ & & $(140)$ \\
\hline
\end{tabular}

Democratic activists do remain poorer and less educated than their Republican counterparts, however. A majority of GOP activists are now at least college graduates. And, upper income political activists are considerably more likely to be Republican than Democrat with only 4.3 percent in the lowest income cohort.

A decade ago, nearly half of Republican Party activists spent their formative years outside of Arkansas. Now, the Arkansas Republican party is 
increasingly a home-grown organization. While 38.7 percent of Republican activists in the most recent survey did live the first 18 years of their life outside of the state (as compared to 16.9 percent of Democrats), there is a decreasing reliance on in-migration for that party. The roots of these nonnative Republicans are still most likely to be in the Midwest as was the case a decade ago. Those few Democrats not native to Arkansas are more evenly distributed in their birthplace, with 2.1 percent actually from a country other than the U.S.

Like other Arkansans, party activists worship almost entirely as Protestants. As shown in Table 2, basic denomination identification is an area of significant overlap for the two parties' local leaders. The one exception in this religious mirroring is the fact that nearly ten percent of Democratic activists are active within the African-American Protestant tradition, a form of religiosity absent from the nearly all-white Arkansas Republican party. While the questions tapping the religious lives of party activists are slightly different than in the 1991 survey, there is little evidence of shifts in this aspect of activists' non-political identifications.

So, nearest the surface-with only a few exceptions-2001 activists look much like their party's activists in 1991. The differences between Democrats and Republicans in these demographics tend to replicate the patterns of a decade ago. Scratching below the surface, as this extensive survey attempts to do, does show distinct shifts in the political attitudes of Arkansas's party activists. The picture presented by this data shows a consistent, increasing polarization of the grassroots workers of the two parties.

\section{Ideology and Issues}

This increased polarization is evidenced first by the two parties' activists' self-placement of themselves on the ideological spectrum. A decade ago, just under 85 percent of Republican activists did describe themselves as "conservative" with slightly less than half of that group choosing the term "very conservative." On the other hand, 1991 Democratic activists were clumped in three fairly even groups: 35.6 percent were "conservative"; 33.1 percent, "moderate"; and, slightly less than one-third, "liberal." The ideological gap of a decade ago has grown into a chasm according to this survey. As shown in Table 3, Arkansas's Democratic activists have liberalized over the past decade, with 44.7 percent now calling themselves "liberals." Conservative Democrats, a decade ago the plurality of grassroots party activists, now make up a meager one-fourth of Democratic activists.

In contrast, over two-thirds of Arkansas Republicans now choose the term "very conservative" to describe themselves. The most "liberal" of Republican activists are now the tiny 5.5 percent who describe themselves as 
Table 3. Ideological Self-Identification of Arkansas Party Activists, 1991 and 2001

\begin{tabular}{lrrrr}
\hline & \multicolumn{2}{c}{ Democrats } & \multicolumn{2}{c}{ Republicans } \\
& 1991 & 2001 & 1991 & 2001 \\
\hline Political Beliefs & & & & \\
$\quad$ Very conservative & 7.5 & 5.5 & 39.5 & 67.3 \\
Conservative & 28.1 & 24.9 & 45.2 & 29.3 \\
Moderate & 33.1 & 30.4 & 12.4 & 3.4 \\
Liberal & 24.0 & 32.6 & 2.6 & - \\
Very liberal & 7.4 & 12.1 & 0.2 & - \\
(N) & $(759)$ & $(365)$ & $(458)$ & $(147)$ \\
Note: Entries are percentages. & & & & \\
\hline
\end{tabular}

"moderates." Any vestige of the Rockefeller Republicanism that had been an important foundation of the Arkansas GOP in the 1960s is now history. While both party's activists have polarized, a key question now comes into focus: Is the Arkansas Republican party in danger of becoming too extreme for an Arkansas mass electorate that has shown a fondness for political candidates - both Democratic and Republican — who have emphasized their moderation and independence?

This increasing polarization is brought home to an even greater degree as we move below the more conceptual self-identification of ideology and examine a series of vital political issues. Table 4 shows the percentage of Democratic and Republican activists, respectively, who indicate either agreement or "strong" agreement with the policy stances presented. In those situations where the questions replicated those on the 1991 survey, that data is also indicated to give insight into the shifts that have occurred within these grassroots activists. And, as can be seen, important shifts have occurred during this era.

On most of the questions that are replicated, Democratic activists have shifted in a more liberal direction on the issue at hand. However, these Democratic shifts typically are smaller-and in some cases much smallerthan are the shifts by Republicans in the opposite direction. For example, Republican activists of 2001 are 22 percentage points more "pro-life" than were GOP activists in 1991; Democratic activists have shifted 9 points in the "pro-choice" direction. On two other issues - the importance of improving the status of women in society and sanctioning prayer in America's public schools-Democratic activists are essentially unchanged in their level of support but these issues are one's on which Republicans have two of their sharpest changes. Among GOP activists, there is now absolutely no dispute 
Table 4. Position on Issues (Agree) for Arkansas Party Activists, 1991 and 2001

\begin{tabular}{lcccc}
\hline & \multicolumn{2}{c}{ Democrats } & \multicolumn{2}{c}{ Republicans } \\
Issue Agreement & 1991 & 2001 & 1991 & 2001 \\
\hline Improve position of women & 84.8 & 81.7 & 52.8 & 28.9 \\
Abortion personal choice & 64.9 & 73.0 & 39.8 & 17.7 \\
Fewer services/reduce spending & 29.9 & 17.0 & 74.8 & 78.4 \\
Permit public school prayer & 77.8 & 77.3 & 84.1 & 98.6 \\
Private school vouchers & $\mathrm{n} / \mathrm{a}$ & 13.4 & $\mathrm{n} / \mathrm{a}$ & 77.0 \\
Improve position of blacks/minorities & 58.7 & 71.9 & 37.2 & 28.4 \\
Insure job/good living standard & 44.4 & 32.7 & 15.3 & 5.4 \\
Women equal role with men & 85.4 & 94.0 & 77.0 & 86.4 \\
Homosexual jobprotection & $\mathrm{n} / \mathrm{a}$ & 54.6 & $\mathrm{n} / \mathrm{a}$ & 10.1 \\
Flat tax & $\mathrm{n} / \mathrm{a}$ & 43.7 & $\mathrm{n} / \mathrm{a}$ & 76.9 \\
Regulate HMOs & $\mathrm{n} / \mathrm{a}$ & 68.0 & $\mathrm{n} / \mathrm{a}$ & 10.7 \\
Blacks preference hiring/promotion & 10.6 & 12.3 & 4.6 & 0.7 \\
Stricter gun control & $\mathrm{n} / \mathrm{a}$ & 61.7 & $\mathrm{n} / \mathrm{a}$ & 5.3 \\
Death penalty for murder & $\mathrm{n} / \mathrm{a}$ & 66.4 & $\mathrm{n} / \mathrm{a}$ & 85.7 \\
& & & & \\
Average N & $(723)$ & $(363)$ & $(443)$ & $(148)$ \\
Note: Entries are percentages of those agreeing & with the stated issue positions. & \\
\hline
\end{tabular}

on school prayer and there has been a precipitous drop in their support for government activism to promote the economic and social status of women. Thus, party activist polarization in Arkansas results disproportionately from Republican shifts during the decade.

Some of the sharpest divergence between Democratic and Republican activists shows itself on topics that were not surveyed in 1991. Gaps of more than 50 percentage points in the levels of support show themselves on gun control (with three-quarters of Democratic activists supporting gun limitations), private school vouchers (with the vast majority of Republican activists supporting this form of school choice), and expanded government regulation of HMOs (with the overwhelming majority of Democratic activists favoring this government activism). Finally, while a majority of Arkansas Democrats favor legislation protecting gay men and lesbians from job discrimination, only a small percentage of Republican activists (10.1 percent) share this view.

The case of gun control serves as an example of the potential dangers that accompany the ideological unity seen among contemporary Republican grassroots activists. Recent surveys of the mass electorate in the state shows that nearly half of Arkansans support stricter gun control. ${ }^{4}$ Thus, both parties' local elites are out of step with Arkansans as a whole, but Republicans 
diverge from rank-and-file Arkansas voters to a considerably larger degree. Indeed, 37 percent of Republican party identifiers support stricter gun control measures! At least on this salient issue, the GOP organization is in danger of disconnecting from the base of voters on which it depends for electoral victories, and to an even greater degree from the independents who are crucial to win in a state now lacking a majority political party.

The apparent stability of the demographic characteristics of Arkansas party activists masks sharp divergence and dramatic shifts in the political worldviews of the activists from the two parties. Arkansas's Republican Party is now a profoundly conservative political party at the grassroots level, while Democratic activists are increasingly in synch with their counterparts in other parts of the country on a variety of issues.

\section{Activists and Their Political Parties}

By a variety of additional measures, the 2001 survey results show that the ideologically united Arkansas Republican party shows itself to be healthier at the local level than the Democratic Party and healthier than was the local GOP in Arkansas in 1991. In her analysis of the 1991 data, Blair noted the variety of ways in which Republican activists perceived their state and local organizations as moving in the right direction in terms of the key roles that those organizations are expected to play. Such optimism remains firmly in place on the part of activists in Arkansas's upstart party boding well for the future of Republicanism in the state. In contrast, just as was the case a decade ago, Democratic activists see many flaws in the recent effectiveness of their party. More important, this relative optimism by Republicans is matched by higher levels of activism and commitment on the part of GOP grassroots workers and lower rates of factionalism within the Republican Party at both the state and local levels.

First, majorities of Republican activists perceive that their party is stronger as an organization, as recruiter of candidates, as a fund-raising entity, as a campaign operation, and as a media presence than a decade earlier. Democrats are much more pessimistic about their party's recent work. For example, only 25.2 percent of Democratic activists see their party as having become stronger as a recruiter of candidates for public office; over two-thirds of Republicans have this perception of their party. Combined with the results from the 1991 survey, Arkansas's Republicans now have at least two decades of consistent momentum in organizational development.

Just as the Republican Party activists are more united ideologically, they are also more allegiant to their party as they self-report their partisan identification. While traces of dual partisanship are shown by Democratic activists' marginally stronger identification with their party at the state level 


\section{2 | Jay Barth}

(contrasting with notable rates of dual partisanship exhibited by both parties' activists a decade ago), examining identification with the national party offers a fair representation of activists' party identification. Arkansas Republican activists' are amazingly united in their level of commitment to their political party with over 96 percent describing themselves as "strong Republicans." While Democrats indicate loyalty to their party (78.9 percent are strong Democrats), the Republican allegiance is unmatchable. Indeed, almost as large a percentage of Democrats identify themselves as Republicans or leaners to the GOP (2.6 percent total) as there are Republican activists who describe themselves as anything other than "strong" Republicans (3.4 percent total). Similarly, while 99.3 percent of GOP activists reported voting for George W. Bush in the 2000 presidential election, over 10 percent of Democratic activists bolted their party to support Bush.

Another measure of attitudes toward the parties - activists' description of their feelings of "closeness to" or "distance from" the parties-reinforces these findings. For instance, almost 85 percent of Republican activists put themselves at one of the two points (on a seven-point scale) closest to the Arkansas state Republican Party and a slightly larger percentage of those activists place themselves at the two most "distant" points from the state Democratic Party. By contrast, only 62.6 percent of Democrat activists place themselves at one of the two "closest" points to their state party, although over three-quarters do similarly distance themselves from the state GOP. This suggests two things: Republicans are more fervent in their party allegiance, and Democrats are driven as much by their animosity toward the political opposition as by their positive feelings for their own party.

This conclusion is reinforced by the survey's results related to the forces that inspire party activists to become and stay involved in their parties. To a much greater degree than their Democratic counterparts, Republican activists claim to have been driven by their interest in and desire to reshape public policies in explaining their involvement in politics. For example, 69.6 percent of GOP activists "see working in the political party generally as a way to influence politics and government" as being "very important"; this is the case for only 43.5 of Democrats. These trends are much like the results from the 1991 survey on similar questions.

Republican activists are also much more likely to "walk the walk" on behalf of their party than are Democrats. The survey asked activists whether they had engaged in thirteen different campaign activities in recent campaigns. As shown in Table 5, on every one of the thirteen, a larger percentage of Republicans than Democrats had engaged in the particular work. Somewhat surprisingly, however, both Republican and Democratic activists report being more active than were those who held these positions a decade ago. Then, a majority of Democrats reported engaging in a lone activity 
Table 5. Campaign Activities of Arkansas Party Activists, 2001

\begin{tabular}{lcc}
\hline & Democrats & Republicans \\
\hline Contributed money to campaigns & 65.1 & 88.0 \\
Distributed posters or lawn signs & 60.1 & 82.7 \\
Distributed campaign literature & 64.3 & 82.0 \\
Arranged fund-raising activities & 24.4 & 64.6 \\
Organized campaign events & 33.6 & 56.7 \\
Sent mailings to voters & 35.4 & 50.0 \\
Organized door-to-door canvassing & 24.1 & 38.0 \\
Dealt with campaign media & 18.9 & 36.0 \\
Organized telephone campaigns & 24.1 & 34.0 \\
Conducted voter registration drives & 19.7 & 23.3 \\
Utilized public opinion surveys & 7.6 & 10.0 \\
Purchased billboard space & 3.4 & 9.7 \\
Helped construct or maintain a campaign website & 2.6 & 3.3 \\
(N) & $(381)$ & $(150)$ \\
Note: Entries are the percent who said that they engaged in the campaign activity in recent elections. & \\
Ns are in parentheses. & & \\
\hline
\end{tabular}

(distributing literature). Now, majorities of Democrats report distributing literature (64.3 percent), distributing lawn signs (60.1 percent), and contributing financially to campaigns (65.1 percent). At least half of Republican activities engage in those three activities plus sending mailings to voters (50.0 percent), organizing campaign events (56.7 percent), and arranging fund-raising activities (64.6 percent). Particularly relevant in an era where fundraising is perhaps the best measure of the health of a party organization, the gap between the levels of activity between activists from the two parties was greatest on this last activity with less than one-fourth of Democrats engaging in an activity that is relatively commonplace for Republicans in Arkansas. ${ }^{5}$

It is also interesting to examine the levels of politics where activists place their energies. A decade ago, a majority of Democratic activists described themselves as "very active" at the local level, outpacing Republican respondents who were "very active" at that level. However, Democratic activists were less likely to be active than were Republicans at the state level and, in particular, in national politics. Republicans were consistent in their activism (ranging between 43 and 46 percent) at the three levels.

At present, Republicans remain generally consistent in the level of politics in which they are most engaged with a slight bias toward state politics. However, the percentage of Republicans who describe themselves as "very active" has jumped considerably, with nearly seven in ten of them 
claiming that level of activity in state politics. Republicans also outpace Democrats in activism at the local level. Showing some additional evidence that the increased Republican activity is being matched by that of the party's competition, some increase in the percentage of Democrats describing themselves as being "very active" has shown itself at all three levels since 1991, but it has been no match for the Republican shifts.

The more diverse Democratic Party is more likely to be viewed as factionalized by its activists than is the Republican party. A slight majority of Democrats see the state party as having "very" or "moderately" high levels of factionalism as compared with 41.7 percent of Republicans. Considering the fact that rifts between the Huckabee and Hutchinson factions within the GOP have occasionally become public in the last several years, it is not surprising that Republicans identify divisions between supporters of different party leaders as one of the greatest source of factionalism in the party. Over 60 percent of Republican activists said that a "great deal" or "fair amount" of disagreement within the party resulted from those divisions. Meanwhile, at the county level, Republicans see minimal factionalism (less than a quarter of activists see signification factionalism); Democrats are much more likely to identify factionalism within the local party (43.6 percent).

Finally, the Republican Party in Arkansas shows itself to be a more vibrant party organizationally than are the Democrats through the considerably greater levels of communication within the party both at the county level and among party actors at the state and federal level. While over 80 percent of Republicans report communicating with the party chair and other county committee members "very often" or "often," this is true for less than two-thirds of Democrats. And, while a majority of Republican activists communicate regularly with state government officials, only 41.6 percent of Democrats interact with the more numerous Democratic state government officials.

\section{Conclusion}

By almost all measures, this analysis of activists on the frontlines of party politics in Arkansas indicates that the Republican Party is a healthier party than it was a decade ago and shows more vibrancy than does the Democrat party at the local level in Arkansas at present. It is a more united party and a more active party at the grassroots level. There are some hints of Democratic party enhancement as well when comparing the 2001 data to the 1991 survey results, however, indicating that - at least to a small degreesharper partisan competition may be promoting increased party development by the traditionally dominant party. 
These results, however, do suggest that there is potential danger, however, for the Republican Party in its cohesiveness. The Arkansas GOP is now a remarkably conservative party across the board. From salient social issues to taxation and spending policies, Republicans are deeply ideological in a conservative direction. The key barrier to Republican success in Arkansas over the past generation has been its difficulty in recruiting candidates with sufficient experience and personal charisma to offer voters increasingly open to voting Republican. While still a challenge to the party, the GOP is more consistently fielding legitimate candidates for political office in Arkansas. One wonders, however, whether the doctrinaire conservative of the candidates who will be able to gain GOP activists' support may develop into just as significant a barrier to those candidates' ultimate success in the years to come.

\section{NOTES}

${ }^{1}$ For fuller analyses of the key political happenings in Arkansas during this era, see Barth, Blair, and Dumas (1999), Barth (1997), and Barth, Parry, and Shields (2002).

${ }^{2}$ For a full discussion of the nature of Arkansas's state and local party organizations at the midpoint of the decade under consideration, see Blair and Barth (1996).

${ }^{3}$ On the purge of "Rockefeller Republicans" after the 1980 election cycle, see Lamis (1988), 120-130.

${ }^{4}$ See the Arkansas Poll, University of Arkansas, fall 1999 (http://plsc.uark.edu/ arkpoll/fall199/policy/GUN3.HTM).

${ }^{5}$ It is important to note that while the same population of activists was used in 2001 as in 1991 for the Democrats - all county party chairs and committee members - and a list that was more expansive in terms of counties covered for the Republicans than in 1991 was employed for that party, the number of individuals on those mailing lists was significantly smaller. This suggests that both parties may have culled their lists to only the most loyal - and therefore, most active - party activists. This does raise questions related to the exactness of the 2001 replication on these questions.

\section{REFERENCES}

Appleton, Andrew M., and Daniel S. Ward. 1994. Understanding Organizational Innovation and Party-Building. In The Changing Role of Contemporary American Parties, eds. Daniel Shea and John Green. Lanham, MD: Rowman and Littlefield.

Barth, Jay. 1997. Arkansas: The Last Hurrah for a Native Son. In The 1996 Presidential Election in the South: Southern Party Systems in the 1990s, eds. Laurence W. Moreland and Robert P. Steed. Westport, CT: Praeger.

Barth, Jay, Diane D. Blair, and Ernie Dumas. 1999. Arkansas: Characters, Crises, and Partisan Change. In Southern Politics in the 1990s, ed. Alexander P. Lamis. Baton Rouge: The Louisiana State University Press. 
Barth, Jay, Todd Shields, and Janine Parry. 2002. Arkansas: Nonstop Action in PostClinton Arkansas. In The 2000 Presidential Election in the South, eds. Robert P. Steed and Laurence W. Moreland. Westport, CT: Praeger.

Bass, Jack, and Walter DeVries. 1977. The Transformation of Southern Politics. New York: New American Library.

Blair, Diane D. 1995a. Arkansas: Emerging Party Organizations. In Southern Party Organizations and Activists, eds. Charles D. Hadley and L. Bowman. Westport, CT: Praeger.

Blair, Diane D. 1995b. The Big Three of Late Twentieth Century Politics: Dale Bumpers, Bill Clinton, and David Pryor. Arkansas Historical Quarterly 54:53-79.

Blair, Diane D. 1994. Arkansas: Ground Zero in the Presidential Race. In The 1992 Presidential Election in the South: Current Patterns of Southern Party and Electoral Politics, eds. Robert P. Steed, Laurence W. Moreland, and Tod A. Baker. Westport, CT: Praeger.

Blair, Diane D., and W. Jay Barth. 1996. Arkansas. In State Party Profiles: A 50-State Guide to Development, Organization, and Resources, eds. Daniel S. Ward and Andrew Appleton. Washington, DC: Congressional Quarterly Press.

Lamis, Alexander P. 1988. The Two-Party South, exp. ed. New York: Oxford University Press. 